\title{
BETA-ADRENERGIC RECEPTORS IN HUMAN ANTERIOR OPTIC NERVE: AN AUTORADIOGRAPHIC STUDY
}

\author{
G. M. B. DAWIDEK and M. I. ROBINSON \\ Cardiff
}

\begin{abstract}
SUMMARY
Sections of human anterior optic nerve and nerve head were incubated in a physiological solution containing a radiolabelled beta blocker at a low concentration. The beta blocker used was (-)-( ${ }^{125}$ iodo)-cyanopindolol, which has a high affinity and specificity for beta-adrenergic receptors. Concurrent incubations were performed with a great excess of unlabelled beta blocker added to demonstrate non-specific binding. Following incubation the sections were washed and dried. They were then apposed to photographic film for 5 days and developed. Incubations were performed with the stereoisomers of propranolol and an alpha blocker as well as specific beta-one and beta-two blockers. Beta-adrenergic receptors were demonstrated in anterior optic nerve and optic nerve head. The majority were of the beta-two subtype.
\end{abstract}

The main group of drugs used in the medical treatment of glaucoma is the topical beta blockers. It is known that they reduce aqueous production, ${ }^{1}$ probably by the inhibition of beta-adrenergic receptors in the ciliary body. They are known to have an effect elsewhere in the body, notably the heart ${ }^{2}$ and chest. ${ }^{3,4}$ It is possible that they may act on other ocular structures either by direct diffusion through the aqueous or via the ocular circulation.

Beta receptors have been identified in the ciliary body in humans ${ }^{5}$ and animals. ${ }^{6}$ They have also been identified in the trabecular meshwork, ${ }^{7}$ cornea, ${ }^{8}$ extraocular muscles, ${ }^{9}$ retina, ${ }^{6}$ retinal vessels ${ }^{10,11}$ and choroid. ${ }^{12}$ They have not so far been identified in anterior optic nerve or nerve head. It has been suggested that reduced perfusion of the optic nerve head leads to optic disc cupping and visual field loss in glaucoma. ${ }^{13}$ Beta receptors mediate dilatation of vascular smooth muscle elsewhere in the body. ${ }^{14}$ Information regarding the presence and nature of beta receptors in anterior opticnerve and particularly the optic nerve head is therefore desirable.

From: Departments of Ophthalmology and Medical Physics, University Hospital of Wales, Cardiff.

Correspondence to: G. M. B. Dawidek, MRCP, FCOphth, Ophthalmic Department, North Staffs Royal Infirmary, Stoke-on-Trent ST4 7LN, UK.
Beta receptors have been divided into beta-one and beta-two subgroups according to a slight difference in the response of various target organs to different pharmacological agents. ${ }^{15}$ The majority of beta receptors already identified in the eye are of the beta-two subtype. Those in the chest, whch mediate dilatation of bronchiolar smooth muscle, are of the beta-two subtype, as are those on vascular smooth muscle. ${ }^{14}$ The bronchospasm induced by non-selective topical beta blockers in susceptible patients is due to inhibition of these. Betaxolol is a beta blocker which is highly selective for beta-one receptors. When administered topically it lowers intraocular pressure ${ }^{16}$ but has less effect on pulmonary function than a non-selective beta blocker. ${ }^{17}$ If beta receptors are present in anterior optic nerve information about their type is also desirable as a selective beta blocker may have a different effect on the beta receptors to a non-selective beta blocker.

In this study we attempted to demonstrate and characterise beta-adrenergic receptors in sections of human anterior optic nerve with an in vitro autoradiographic technique which has been used before to demonstrate beta receptors elsewhere in the eye. ${ }^{6}$ The radioligand used was (-)- $\left({ }^{125}\right.$ iodo)-cyanopindolol (ICYP), which has previously been demonstrated to have a very high affinity and specificity for beta-adrenergic receptors. ${ }^{18}$

\section{METHODS}

Human anterior optic nerve and nerve head were removed within 16 hours of death from donor eyes with no history of ocular disease. The structures were mounted in TissueTek and snap frozen in isopentane cooled in liquid nitrogen at $-80^{\circ} \mathrm{C}$. They were stored at the same temperature. Sections $8 \mu \mathrm{m}$ thick were cut on a cryostat at $-20^{\circ} \mathrm{C}$ (Bright Instruments, Huntingdon, UK) and mounted on gelatine-coated glass slides. The slides were then brought to room temperature and placed in an incubation medium comprising $150 \mathrm{mmol} / \mathrm{l}$ sodium chloride, $50 \mathrm{mmol} / \mathrm{l}$ Tris$\mathrm{HCl}$ buffer at $\mathrm{pH} 7.5,10 \mathrm{mmol} / \mathrm{l}$ magnesium chloride, $1 \mathrm{mmol} / \mathrm{l}$ ascorbic acid and $10 \mu \mathrm{mol} / \mathrm{l}$ phenylmethylsulphonylfluoride to which ICYP had been added. Between 
20 and $50 \mathrm{pmol} / \mathrm{l}$ ICYP was used. After 45 minutes of incubation the slides were washed in distilled water for 20 seconds followed by three washes of 10 minutes each in ice-cold buffer. They were then washed for a further 20 seconds in distilled water. The slides were then dried in a stream of cold air and apposed to Hyperfilm 3H (Amersham, UK) in light-tight cassettes for 5 days. The film was developed in D19 (Kodak, UK) for 4 minutes, fixed in Unifix (Kodak, UK) for 4 minutes, washed in cold running water and dried.

Non-specific binding was determined by incubating adjacent sections in separate buffer which contained $10 \mu \mathrm{mol} / \mathrm{l}$ unlabelled propranolol in addition to ICYP. Further incubations were performed with similar sections and concentrations of ICYP but with a variety of unlabelled drugs added. These included $10 \mu \mathrm{mol} / \mathrm{l}$ phentolamine, an alpha blocker; $2 \mathrm{nmol} / \mathrm{l}(+)$ - and (-)-propranolol, the stereoisomers of propranolol; $1 \mu \mathrm{mol} / \mathrm{l}$ and $50 \mathrm{nmol} / \mathrm{l}$ ICI 89,406, a specific beta-one blocker; and $1 \mu \mathrm{mol} / \mathrm{l}$ and $25 \mathrm{nmol} / \mathrm{l}$ ICI 118,551, a specific beta-two blocker.

Propranolol and ICI 89,406 were kindly provided as gifts by Imperial Chemical Industries, Macclesfield, UK. ICI 118,551 was purchased from Cambridge Research Biochemicals, Northwich, UK. The remaining drugs were all purchased from Sigma Chemical Co., Poole, UK.

Every fifth section was stained with haematoxylin and eosin instead of undergoing incubation, to demonstrate anatomical location.

\section{RESULTS}

There was a marked difference in density of labelling between sections incubated with ICYP alone and those incubated with a great excess of unlabelled propranolol.

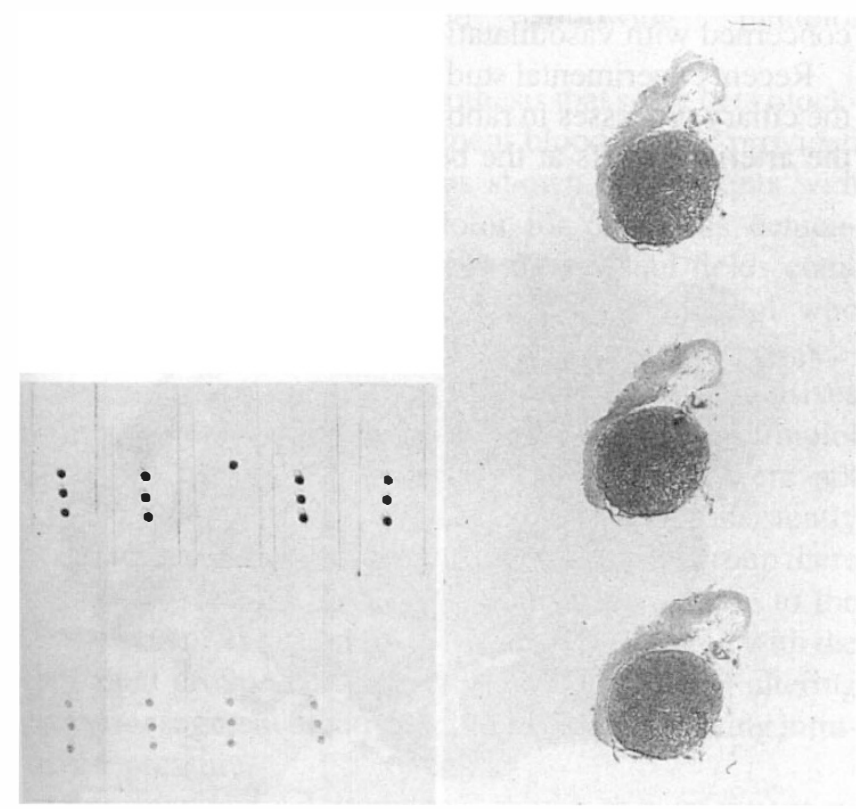

Fig. 1. Left: Autoradiograph of sections of anterior optic nerve. The upper sections were incubated with 20 pmol/l ICYP alone. The lower sections were incubated with ICYP and $10 \mu \mathrm{moll}$ l unlabelled propranolol. Right: Photomicrograph of adjacent sections of anterior optic nerve. Haematoxylin and eosin, $\times 6$.
Particularly dense labelling was present on the optic nerve itself in the sections of anterior optic nerve (Fig. 1) and optic nerve head (Fig. 2). This tissue-specific binding using small concentrations of ligand which could be inhibited by a great excess of unlabelled beta blocker strongly suggested that beta receptors were present in both anterior optic nerve and nerve head. No difference in binding occurred with the addition of $10 \mu \mathrm{mol} / \mathrm{l}$ phentolamine and $2 \mathrm{nmol} / \mathrm{l}(+)$-propranolol. However, there was reduced binding with $2 \mathrm{nmol} / \mathrm{l}(-)$-propranolol which is the active stereoisomer of propranolol. These results provided further support for the presence of specific binding to beta receptors.

Radiolabelled beta blockers are known to bind nonspecifically to melanin..$^{19}$ Melanocytes have been reported in the region of the optic nerve head. ${ }^{20}$ We identified melanocytes surrounding the optic nerve and in the sclera in the sections of optic nerve head stained with haematoxylin and eosin (Fig. 2). These correlated well with areas of non-specific binding on the autoradiographs. No melanocytes were present in the optic nerve itself in either anterior optic nerve or optic nerve head.

Incubation with $1 \mu \mathrm{mol} / \mathrm{l}$ and $25 \mathrm{nmol} / \mathrm{l}$ ICI 118,551 (Figs. 3 and 5) resulted in a very marked reduction in binding. With $1 \mu \mathrm{mol} / \mathrm{l} \mathrm{ICI} 89406$ (Fig. 4a) there was moderate reduction in binding whereas with $50 \mathrm{nmol} / \mathrm{l} \mathrm{ICI}$ 89,406 (Fig. 4b) there was a smaller alteration in binding. This suggests that the great majority of beta receptors in anterior optic nerve and optic nerve head are of the betatwo subtype.

\section{DISCUSSION}

These experiments clearly show that beta receptors are present in anterior optic nerve and optic nerve head. Furthermore, the great majority of receptors are of the beta-two subtype. The resolution of the technique was insufficient to localise beta receptors to particular structures in the optic nerve head. The relatively high specific

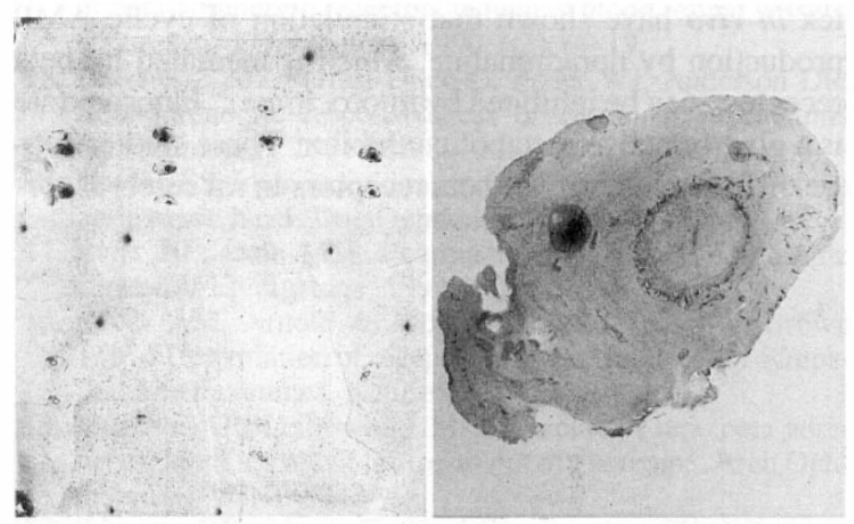

Fig. 2. Left: Autoradiograph of sections of optic nerve head. The upper sections were incubated with 40 pmolll ICYP alone. The lower sections were incubated with ICYP and $10 \mu \mathrm{mol} / \mathrm{l}$ unlabelled propranolol. Right: Photomicrograph of adjacent section of optic nerve head. Melanocytes are present surrounding the optic nerve and scattered through the sclera. They corresponded to areas of non-specific binding in the lower sections in the autoradiograph. Haematoxylin and eosin, $\times 6$. 


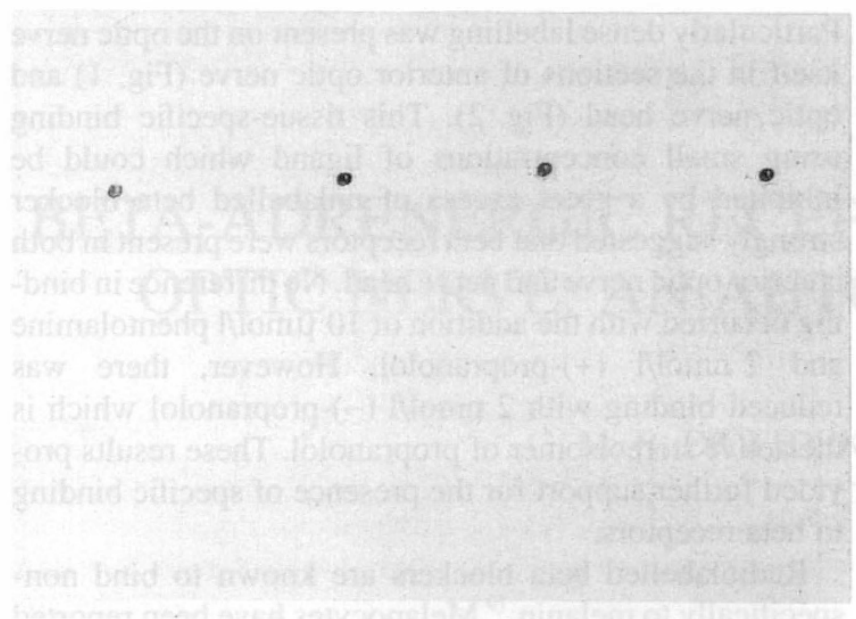

Fig. 3. Autoradiograph of sections of optic nerve head. The upper sections were incubated with 20 pmol/l ICYP alone. The lower sections, which are barely visible, were incubated with ICYP and $25 \mathrm{nmol} / \mathrm{l}$ ICI 118,551.

activity of iodine-125 produced uniform fogging of the film over the entire optic nerve. Furthermore the anatomical register of the film with the slides was lost when the film was removed for development.

Beta receptors could be present either on blood vessels or on glial cells. Beta receptors have, as stated above, already been identified on retinal vessels in both animals ${ }^{10}$ and humans. ${ }^{11}$ The majority of these are of the beta-two subtype. Moreover they have been localised to blood vessels elsewhere in the body as, for example, in the heart, ${ }^{21}$ internal mammary artery and saphenous vein. ${ }^{22}$ These are also mainly of the beta-two subtype. They have also been identified elsewhere in the central nervous system on cerebral microvessels. ${ }^{23}$ Again the great majority of these are of the beta-two subtype. ${ }^{24}$ These findings support the suggestion that beta receptors are present on blood vessels in anterior optic nerve.

There is some support for the other possibility, that the receptors may be on glial cells. Studies on rat cerebral cortex in vivo have shown that stimulation of cyclic AMP production by noradrenaline, which is mediated by beta receptors, can be inhibited by fluorocitrate.$^{25}$ Fluorocitrate is a glial-selective metabolic inhibitor. These studies suggest that the majority of beta receptors in rat cerebral cor-

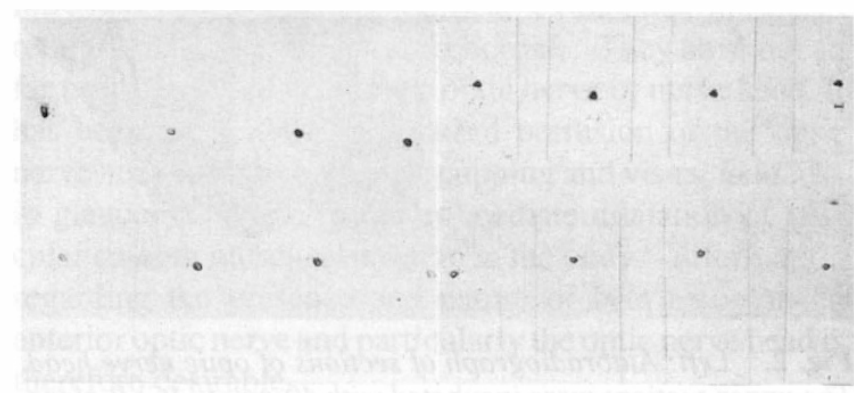

Fig. 4. Autoradiographs of sections of optic nerve head. Left: The upper sections were incubated with 20 pmolll ICYP alone. The lower sections were incubated with ICYP and 1 mmol/l ICI 89,406. Right: The upper sections were incubated with 20 pmol/l ICYP alone. The lower sections were incubated with ICYP and $50 \mathrm{nmol} / \mathrm{l} \mathrm{ICI} \mathrm{89,406.}$ tex are situated on glial cells. However, this response is selectively antagonised by ICI 89,406 , which indicates beta receptors on glial cells are predominantly of the betaone subtype.

There was a very marked reduction in the binding of ICYP in sections incubated with both $1 \mu \mathrm{mol} / \mathrm{l}$ and $25 \mathrm{nmol} / \mathrm{l}$ ICI 118,551 , a specific beta-two antagonist. There was a moderate reduction in binding in sections incubated with $1 \mu \mathrm{mol} / \mathrm{l} \mathrm{ICI} 89,406$, with a smaller change when the $50 \mathrm{nmol} / \mathrm{l}$ concentration was used. Other studies on beta receptors elsewhere in the eye have concluded that the beta-two receptor subtype predominates although beta-one receptors are also present in significant numbers. ${ }^{6}$ However ICI 89,406, although principally a beta-one antagonist, does have some beta-two antagonist activity as well. Pharmacological studies on ICI 89,406 have shown that its dissociation constants for beta-one and beta-two receptors are $1.4 \times 10^{-9}$ and $3.8 \times 10^{-7}$ respectively. ${ }^{26}$ At $1 \mu \mathrm{mol} / \mathrm{l}$ it would therefore be expected to have beta-two antagonist activity as well. Some of the reduction in binding of ICYP observed at this concentration may have been due to this rather than to beta-one antagonism. At $50 \mathrm{nmol} / \mathrm{l}$ much less beta-two antagonist activity was present and there was less change in binding. Furthermore, ICI 118,551 at the lower concentration of $25 \mathrm{nmol} / \mathrm{l}$ almost completely abolished binding of ICYP. At this low concentration it has almost entirely beta-two antagonist activity. ${ }^{27}$ These findings strongly suggest that the great majority of beta receptors in anterior optic nerve are of the beta-two subtype.

Beta-two receptors are found in vascular beds such as skeletal muscle and stimulation of these results in vasodilatation. ${ }^{14}$ It is possible that the beta-two receptors found in anterior optic nerve are situated on blood vessels and are concerned with vasodilatation.

Recent experimental studies on the arterioles supplying the ciliary processes in rabbits have shown constriction of the arteriolar cuffs at the beginning of these vessels fol-

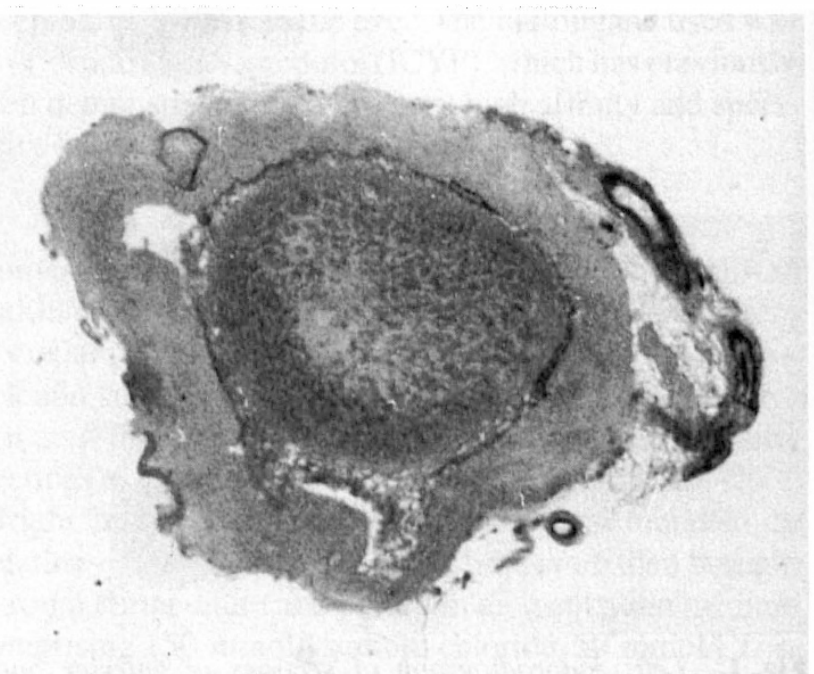

Fig. 5. Photomicrograph of section of optic nerve head cut posteriorly from the same specimen as the sections used for incubations shown in Figs. 3 and 4. Haematoxylin and eosin, $\times 16$. 
lowing single-dose administration of timolol and betaxolol. ${ }^{28}$ This constriction is maintained over 7 weeks with timolol but with betaxolol the constriction wanes over the same period. This may be related to the selective beta blocking activity of betaxolol. Betaxolol selectively blocks beta-one receptors whereas timolol, which is nonselective, blocks both beta-one and beta-two receptors. The beta receptors in the ciliary processes are predominantly of the beta-two subtype. ${ }^{5}$ It is possible that the mainly beta-one antagonist activity of betaxolol is insufficient to produce prolonged beta-two blockade with constriction of the arteriolar cuff. Timolol, however, could have sufficient beta-two antagonist action to cause persisting constriction of the arteriolar cuff.

If a similar process were to occur in posterior segment vasculature such focal vasoconstriction could affect the vessels supplying the optic disc and cause ischaemia of optic nerve fibres.

Visual function can be assessed by measurement of the differential light threshold. This was measured in glaucoma suspects before and after single doses of various glaucoma medications. ${ }^{29}$ Timolol, acetazolamide and pindolol all produced a reduction in intraocular pressure. With acetazolamide the differential light threshold tended to improve, whereas with timolol it tended to deteriorate. From this it was suggested that timolol, a non-selective beta blocker with no intrinsic sympathomimetic activity, had, in addition to reducing intraocular pressure, caused an alteration in blood flow to the posterior segment. Pindolol, although non-selective, is a beta blocker with intrinsic sympathomimetic activity which might be expected to exert at least a partial protective effect on posterior segment blood flow. There was no overall change in the differential light threshold following pindolol administration.

Further support for the hypothesis that some beta blockers might alter posterior segment blood flow is provided by a clinical study which has shown that patients with glaucoma treated with pindolol for 6 months demonstrated a slight improvement in their visual fields compared with a similar group treated with timolol who showed a slight deterioration. ${ }^{30}$ A much longer prospective clinical study of a large group of ocular hypertensives involved random allocation of half the group to timolol treatment for up to 6 years. ${ }^{31}$ The other half were not treated. Although timolol successfully and consistently reduced the intraocular pressure in the treated group there was no significant difference in the average time to the development of glaucomatous changes compared with the untreated group. This is consistent with timolol altering posterior segment blood flow in addition to reducing intraocular pressure.

A recent clinical study has shown that treatment of patients with established glaucoma with the selective beta blocker betaxolol over an 18-month period resulted in better survival and improvement of the visual field than in a similar group treated with timolol. ${ }^{32}$ The presence of almost entirely beta-two receptors in the vessels of the optic nerve head combined with these findings suggests that the use of a selective beta-one blocker such as betaxolol may be preferable to a non-selective beta blocker in the treatment of glaucoma.

We wish to thank the Bristol Eye Bank, Dr. J. Brown, Mr. J. M. Jones, Prof. R. Marks, Dr. J. W. Neal, Mr. A. R. Richards and Mr. S. Gaskell for their kind help and advice. This work was supported by a grant from the Welsh Scheme for the Development of Health and Social Research (RM 682/1).

Key words: Autoradiography, Beta-adrenergic receptor, Optic nerve, Optic nerve head.

\section{REFERENCES}

1. Yablonski ME, Zimmerman TJ, Waltman SR, Becker B. A fluorophotometric study of the effect of topical timolol on aqueous humour dynamics. Exp Eye Res 1978;27:135-42.

2. Leier CV, Baker ND, Weber PA. Cardiovascular effects of ophthalmic timolol. Ann Intern Med 1986;104:197-9.

3. Jones FL, Ekberg NL. Exacerbation of asthma by timolol (letter). N Engl J Med 1979;301:270.

4. Schoene RB, Martin TR, Charan NB, French CL. Timololinduced bronchospasm in asthmatic bronchitis. JAMA 1981;245:1460-2.

5. Wax MB, Molinoff PB. Distribution and properties of betaadrenergic receptors in human iris-ciliary body. Invest Ophthalmol Vis Sci 1987;28:420-30.

6. Elena P, Kosina-Boix M, Moulin G, Lapalus P. Autoradiographic localisation of beta-adrenergic receptors in rabbit eye. Invest Ophthalmol Vis Sci 1987;28:1436-41.

7. Jampel HD, Lynch MG, Brown RH, Kuhar MJ, de Souza EB. Beta-adrenergic receptors in human trabecular meshwork. Invest Ophthalmol Vis Sci 1987;28:772-9.

8. Lehto I, Palkama A, Raij K, Uusitalo H, Lehtosalo J. Autoradiographic study on the location of beta-adrenergic receptors in the cornea and ciliary body. Proc Int Soc Eye Res 1984;3:63.

9. Van Pinxteren PCM, Van Alphen GWHM. Extraocular rectus muscles of the rabbit contain alpha-two and beta-two adrenergic receptors. Curr Eye Res 1985;4:989-93.

10. Ferrari-Dileo G. Beta-one and beta-two adrenergic binding sites in bovine retina and retinal blood vessels. Invest Ophthalmol Vis Sci 1988;29:695-9.

11. Denis P, Elena P, Lapalus P. Autoradiographic localisation of beta-adrenergic receptors in human blood retinal vessels. Chibret Int J Ophthalmol 1990;7(3):14-19.

12. Grajewski AL, Ferrari-Dileo G, Feuer WJ, Anderson DR. Beta-adrenergic responsiveness of choroidal vasculature. Ophthalmology 1991;98:989-95.

13. Hayreh SS. Inter-individual variation in blood supply of the optic nerve head. Doc Ophthalmol 1985;59:217-46.

14. Rang HP, Dale MM. Pharmacology, 2nd ed. Edinburgh: Churchill Livingstone, 1991:183.

15. Lands AM, Arnold A, McAuliff JP, Luduena FP, Brown TG. Differentiation of receptor systems activated by sympathomimetic amines. Nature 1967;214:597-8.

16. Berrospi AR, Leibowitz HM. Betaxolol. A new beta-adrenergic blocking agent for treatment of glaucoma. Arch Ophthalmol 1982;100:943-6.

17. Schoene RB, Abuan T, Ward RL, Beasley CH. Effects of topical betaxolol, timolol and placebo on pulmonary function in asthmatic bronchitis. Am J Ophthalmol 1984;97: 86-92.

18. Hoyer D, Engel G, Berthold R. Binding characteristics of $(+)-,( \pm)-$ and $(-)-\left({ }^{125}\right.$ iodo)cyanopindolol to guinea-pig left ventricle membranes. Naunyn Schmiedebergs Arch Pharmacol 1982;318:319-29.

19. Trope GE, Clark B, Titinchi SJS. Identification of beta- 
adrenergic receptors in the pigmented mammalian iris-ciliary body diaphragm. Exp Eye Res 1982;34:153-7.

20. Spencer WH. Optic nerve. In: Spencer WH, editor. Ophthalmic pathology: an atlas and textbook. Philadelphia: Saunders, 1986:2345-6.

21. Buxton BF, Jones CR, Molenaar P, Summers RJ. Characterisation and autoradiographic localisation of beta-adrenoceptor subtypes in human cardiac tissue. Br J Pharmacol. 1987;92:299-310.

22. Molenaar P, Malta E, Jones CR, Buxton BF, Summers RJ. Autoradiographic localisation and function of beta-adrenoceptors on the human internal mammary artery and saphenous vein. Br J Pharmacol 1988;95:225-33.

23. Kobayashi H, Memo M, Spano PF, Trabucchi M. Identification of beta-adrenergic receptor binding sites in rat brain microvessels using $\left({ }^{125} \mathrm{I}\right)$ iodohydroxybenzylpindolol. J Neurochem 1981;36:1383-8.

24. Kobayashi H, Maoret T, Ferrante M, Spano PF, Trabucchi M. Subtypes of beta-adrenergic receptors in rat cerebral microvessels. Brain Res 1981;220:194-8.

25. Stone EA, John SM. Further evidence for a glial localisation of rat cortical beta-adrenoceptors: studies of in vivo cyclic AMP responses to catecholamines. Brain Res 1991;549: 78-82.
26. Engel G, Hoyer D, Berthold R, Wagner H. ( \pm$)\left({ }^{125}\right.$ iodo) cyanopindolol, a new ligand for beta-adrenoceptors: identification and quantitation of subclasses of beta-adrenoceptors in guinea pig. Naunyn Schmiedebergs Arch Pharmacol 1981;317:277-85.

27. Bilski AJ, Halliday SE, Fitzgerald JD, Wale JL. The pharmacology of a beta-two selective adrenoceptor antagonist (ICI 118,551). J Cardiovasc Pharmacol 1983;5:430-7.

28. Van Buskirk EM, Bacon DR, Fahrenbach WH. Ciliary vasoconstriction after topical adrenergic drugs. Am J Ophthalmol 1990;109:511-17.

29. Flammer J, Drance SM. The effect of a number of glaucoma medications on the differential light threshold. Doc Ophthalmol Proc Ser 1983;35:145-8.

30. Flammer J, Robert Y, Gloor B. Influence of pindolol and timolol treatment on the visual fields of glaucoma patients. $\mathrm{J}$ Ocul Pharmacol 1986;2:305-11.

31. Schulzer M, Drance SM, Douglas GR. A comparison of treated and untreated glaucoma suspects. Ophthalmology 1991;98:301-7.

32. Messmer C, Flammer J, Stumpfig D. Influence of betaxolol and timolol on the visual fields of patients with glaucoma. Am J Ophthalmol 1991;112:678-81. 